\title{
Local Government capacity in the Southern African Development Community (SADC) Region
}

\author{
Purshottama Reddy, John-Mary Kauzya \\ University of Kwazulu Natal, Durban \\ cross $^{\text {ref }}$ http://dx.doi.org/10.5755/j01.ppaa.14.3.13432
}

\begin{abstract}
Adequate country capacity is a key consideration in global efforts to meet the Millennium Development Goals (MDGs). The Organization for Economic Co - operation and Development (OECD) has pointed out that even if there were greater financial resources for capacity development in many developing countries, it is still likely to fail. Capacity development has also moved beyond the individual level in terms of knowledge and skills to a focus on the quality of leadership and management of the public institution and organization. However, irrespective of the governmental structure, it is a given that local governments globally play a critical role in local governance by promoting local development and ultimately the MDGs. However, the level of public governance in many countries is still too weak to make a significant impact in terms of accelerating the pace to reach the MDGs. This paper will critically review the attainment of the Millennium Development Goals in the Southern African Development Community (SADC) Region with a particular emphasis on the local sphere of government. There are currently twelve countries in the SADC Region; however, this study will focus on a representative sample of countries, notably South Africa, Botswana, Malawi, Mozambique and Zimbabwe. The countries chosen vary in size, physical attributes and political dynamics and more importantly in terms of levels of development. Adequate capacity is one of the critical missing factors in current interventions to attain the MDGs and other national development goals.
\end{abstract}

Keywords: Millennium Development Goals; South African Development Community (SADC) Region; local government; capacity development.

Raktažodžiai: Tūkstantmečio vystymosi tikslai (TVT); Pietu Afrikos Vystymo Bendruomenès (PAVB) Regionas; vietos valdžia; gebẻjimu vystymas.

\section{Introduction}

The issue of capacity is a key issue in global efforts to ensure the Millennium Development Goals (MDGs) are attained. The allocation of greater financial 
resources to the attainment of the MDGs does not necessarily mean that it will be achieved. Finance is just one part of the equation in terms of meeting the goals and targets set in the MDGs. Key to this development process is capacity at all spheres of government which will be the determining factor. In this context, the notion of capacity development has also moved beyond the individual level in terms of knowledge and skills to a focus on the quality of public leadership and management in the institution and organization. It should be noted that the operations of public institutions and organization are to a large extent also influenced by the enabling environment at that particular point in time, more specifically the influence and structures of power and the public institutional culture in which they have been embedded over the years [19, p. 11]. Local governments globally irrespective of the systems and structures of local governance play a pivotal role in promoting local development and ultimately the MDGs. However, the quality of governance particularly in many developing countries is still not strong enough to make a positive impact in terms of accelerating the pace to reach the MDGs [23, p. 1]). The deadline for achieving the MDGs is 2015 and it is unlikely that the majority of developing countries will in fact meet that goals and targets set.

The Southern African Development Community (SADC) Region was created in terms of a Declaration and Treaty signed in Windhoek, Namibia in July 1992. It consists of twelve countries namely, Angola, Botswana, Democratic Republic of Congo, Lesotho, Malawi, Mauritius, Mozambique; Namibia; Seychelles; South Africa; Swaziland, Zambia, Zimbabwe and Tanzania [1, p. 3].

This paper will review the attainment of the Millennium Development Goals in the Southern African Development Community Region of the African Continent. It will initially provide a background of the Region, a SWOT (strengths, weaknesses; opportunities and threats) analysis based on the existing knowledge and literature studies of local government in each of the countries selected in terms of addressing the MDGs. In addition, it will highlight some of the key challenges for the attainment of the MDGs in an African context and more importantly, what needs to be done in terms of addressing the capacity constraints in meeting goals and the required targets. Decentralization strategies and initiatives in each of the countries will also be reviewed in a broader capacity development context.

\section{Local Government in the Region}

The South Africa democratic state, ushered in April 1994, was committed to addressing the issue of inequality and poverty which was high on the municipal agenda. Since then, a systematic process has been in place whereby new policies designed to enhance the quality of life at the local level were introduced thereby moving to a more equitable society. To this end, each successive administration appointed by the ruling party has contributed to development successes in terms of building blocks, as well as responding to challenges on an ongoing basis at that particular point of time in the broader context of growth and development. 
The country is a unitary state and is a constitutional democracy with three distinct spheres of government, that is, national, provincial and local. The governmental system consists of nine provinces which are in turn divided into 278 municipalities ( 8 metropolitan; 44 districts and 226 local). The three distinct categories of municipalities constitutionalized, in terms of chapter 7 are Metropolitan (A), (exercising all local government powers); local (B) (sharing powers and functions) and constituting a district (C). The objectives of local government as defined in section 152 are to provide democratic and accountable government; ensure provision of sustainable services; promote socio - economic development; ensure a safe and healthy environment and local community involvement. Municipalities have to in terms of section 53 "structure and manage its administration and budgeting and planning processes to give priority to the basic needs of the community, and to promote the social and economic development of the community and participate in national and provincial development programs" A municipality is considered well capacitated and functional if it can, within its financial and administrative capacity achieve the objectives detailed above [17, p. 7].

There are few African countries that have adequate data in terms of addressing the goals and targets of the MDGs and South Africa is one of them. The country has proved to be quite interesting as it presents a mixed picture in terms of development. The MDGs have been achieved in some cases, whereas in others it is still lagging behind. It is generally accepted that government intervention is imperative to ensure that the goals and targets set are achieved. Intervention by Government is crucial in attaining those goals in terms of meeting the 2015 deadlines. The country has a stable macro economy and private sector, reasonably good infrastructure and more importantly is not reliant on donor funding; however, access to quality education and health is still very much viewed as major challenge for the majority of the populace [18, p. 3], despite South Africa becoming a democratic state in 1994. There is a strong view that the attainment of the MDGs in South Africa will depend on how the key role-players and stakeholders manage to mobilize public resources in the broader governance context. In the South African case, the MDG process has also unearthed some deficiencies in the quality of data and the resultant gaps that has come about $[18$, p. 3].

Botswana is a landlocked country with an estimated population of 1950000 in 2009. Geographically the country covers an area of approximately $582000 \mathrm{~km}^{2}$ and a major part of the country is covered by the Kalahari Desert [UNDESA 2009]. A liberal democratic regime was ushered in at independence in 1966. The Tenth National Development Plan (2009 -2016) is the policy instrument used by the Government to steer progress on the MDGs over the next four years. Prudent macro economic management complemented by strong public institutions coupled with good governance has facilitated economic growth which has in turn paved the way in terms of progressively moving towards the MDG targets [5, p. 10-11].

Botswana with a bicameral parliament is a democratic republic which consists of the elected National Assembly and the hereditary, advisory House of Chiefs. The 
President is the Head of State and government and is indirectly elected by the members of the national assembly for two five year terms. Fifty seven of the 63 national assembly members are elected directly through universal adult suffrage under the first past the post system; four appointed by the President while the President and the attorney general make up the other two in an ex - officio capacity. The President appoints a Cabinet of Ministers from the national assembly and nonelected members can also be appointed. The House of Chiefs which has only advisory and not legislative powers, has a total of 35 members, namely the chiefs of the eight principal tribes, 22 members elected directly by the house and a further 5 appointed by the President [8, p. 34].

Botswana has been categorized as a unitary state and has a two - tier system of government, i.e. central and local ${ }^{1}$.The latter comprises of district/urban councils, land boards, tribal administration and the office of the district commissioner [11, p. 23]. At present, there are 16 local councils (10 districts, 4 towns and 2 cities), an increase of 7 since they were first established in 1966.

Local authorities have to provide basic social and infrastructural services which includes inter alia, primary schools, primary health care and sanitation services; public roads, rural water supplies, markets, parks cemeteries, relief services, recreation and welfare, commerce, abattoirs and regulation of beer halls.

Mozambique has a population of approximately 20.3 million people and occupies an area of $799380 \mathrm{~km}^{2}$. There is approximately $70 \%$ of the population living in in rural areas and 5\% live in the capital city of Maputo. Following a ten year war for independence from Portugal which was granted in 1975, a lengthy civil war ensued where almost a million people lost their lives and the state became dysfunctional [11, p. 142]. During the colonial era, there was limited investment in training of local staff and infrastructure. The country was then believed to be the poorest internationally with external debt of $200 \%$ of the GDP and poverty level above $80 \%$ and inflation running at 50\%. Economic change commenced earnestly in 1987 followed by political changes in 1990 [11, p. 142]. Together with the support and co - operation of international development partners, a turnaround strategy was introduced resulting in a two figure growth rate; poverty reduction by $15 \%$ and inflation to a single digit figure and external debt levels to below $35 \%$ of GDP [16, p. 6]. All of this took place at a time when there was flooding, droughts and the global economic crisis. The MDGs have been integrated in the National Agenda for the Fight Against Poverty. Attempts have also been made to reduce climate change damage; impoverishment of the coastal and marine ecosystems (highlighted in the 2010 Gender, Environmental and Climate Change Strategy and Action Plan) and increase seawater level. Furthermore, Presidential initiatives were introduced to crystallize MDGs challenges,

\footnotetext{
${ }^{1}$ In terms of a recent policy directive, "local authority" is reserved only for councils. Land Boards, District Administration and Tribal Administration are referred to as local institutions (Presidential Directive (CAB 22/2005) as cited in (Kathyola and Job 2011: 142).
} 
namely the Presidential Initiative on Maternal and Child Health; "One Student One Tree Per Year" and "One Community Forest" [16, p. 3].

There are 43 municipal governments in the urban areas and 128 rural districts in Mozambique. Two basic policy documents have guided the strategic agenda, namely "Agenda 2025" and the ten year "Global Strategy for Public Sector Reform (2001 2011)." These policy documents view decentralization as the basis of modernization of the state [11, p. 142].

In comparing the different countries in the Region, it is obvious that the countries discussed have different geographical and physical attributes that have also impacted on local governance. They vary in size, population and history and the majority of them are coastal while Botswana is landlocked. All the countries have adopted a multi - party system and free and fair elections which are held fairly regularly. All the countries which attained independence in the 1960s (South Africa in 1994) focused on state/nation building opting for a stronger system of local government in line with their preference for democracy at the national level. However, a decade later, two of the countries, namely Mozambique and Tanzania adopted autocratic models of governance and consequently stronger systems of field administration or deconcentration became the norm. In the early 2000s virtually all the countries redirected all their energies towards the Millennium Development Goals and more specifically reducing poverty by half by 2015 [11, p. 228].

Malawi is a country with a high population density and is landlocked. It is one of the world's poorest countries. It gained independence in July 1964 and the country was proclaimed a one party state shortly thereafter by the then Constitution (Act 23 of 1966). At that stage, all public institutions including local government were subordinate constitutionally to the Malawi Congress Party which in fact was the de facto Government of Malawi. Consequently, the relationship between local government and the higher levels of government was best described as one of deliberate superiority and subordination. The politicians, be they legislators or councilors had to be members of the ruling Party and subject to its Constitution, rules and regulations ([1, p. 15]. The political transition of 1994 provided an opportunity to restructure the public sector and economy and it was a joint initiative by the Government and development partners. A poverty reduction program focusing on restructuring the roles of the public, private and civil society sectors was introduced placing emphasis on more open and democratic governance. This program was developed over time culminating in the 2002 Poverty Reduction Strategy (PRSP) that was considered a strategic plan for addressing the needs of the country. Economic and public sector performance has been weak over the past ten years. Furthermore, economic restructuring has been slow and uneven; macro - economic stability has not been achieved and economically the country has not moved to a higher growth path.

Chapter XIV of the Constitution makes provision for local government and the Minister of Local Government and Community Development is responsible for overseeing local government. There are currently 35 single tier authorities, 4 cities, 28 district councils, 2 municipal councils and I town council. 
Zimbabwe gained independence in 1980 and is a unitary state. Since then, the Government has declared its policy intention to promote decentralization based on the principles of subsidiarity. There were several institutional innovations to support this over the years.

More specifically, the District Council Act was initially enacted in 1982 and the amended in 1981 and 1982. The Act was only applicable to communal lands and was re - introduced following the period of insurgency by the guerrillas. This resulted in some consolidation where the previously fragmented authorities were reduced from 220 to 55 and resulted in the system being democratized [1, p. 19].

The Local Government System is governed by inter alia, Provincial Councils and Administration Act; Urban Councils Act; Rural District Councils Act; Regional Town and Country Planning Act and the Traditional Councils. There are presently twenty eight Urban Councils in the country as provided in Chapter 29: 15 of the Urban Councils Act. Local Boards are the lowest on the hierarchy of urban councils that have been established in settlements where the population is very small and they have peculiar circumstances. but they have the potential to grow into large centers. Government assistance is also required in terms of funding. There are currently 8 town councils which have grown from service centers in the rural areas sufficient for them to be independent. The third position is held by ten municipal councils and six city councils currently have the highest status nationally. Rural district councils which currently number 58 are in existence throughout the country and have been created in terms of the District Councils Act [26] .

\section{Rationale and Objectives of Decentralization in the Region and for African Countries in General}

Big and complex jobs require strong and complex capabilities. Through policies and strategies of decentralization, local governments in Africa are at the fore front of local level development, often with fewer resources. Local level public servants at political, administrative/managerial, and technical levels are under pressure to make and implement decisions on issues which are highly complex that has major implications on development in their constituencies. As a logical consequence, they must and are expected to be able to deal with issues ranging from economic development to personnel law, land-use planning, running meetings which are effective, environment, leadership, HIV/AIDS, education, primary healthcare in addition to very traditional functions of local administration to achieve the desired objectives of many decentralization policies in Africa.

If one has to reflect on the reasons dedicated to enhancing public administration at the local government level in Africa, perhaps the starting point should be to determine in the first place the objectives that have guided decentralization and local governance on the continent. In other words the overriding question should be: Strengthening public administration capacity-building to achieve what? Basically, in a general way one can say that decentralization policy objectives that are clearly set 
out are a basic element of capacity. Public administration capacity in local governments need to be developed to achieve socio-politico-economic development objectives at the local level thereby ensuring a positive change in the lives of grassroots communities who in the majority of cases suffer abject poverty. It is imperative therefore that the objectives of decentralization in African countries be explored to determine the rationale for strengthening public administration at the local level.

Decentralization signifies the transferring of authority, be it legislative, administrative or judicial and administrative from a higher to a lower level. The sharing of decision-making authority with the lower levels in the organization constitutes the basis of this policy. There could be a sharing of power within the system, or new mechanisms could be created internally or with outside agencies and organizations [White, Reddy, Department of Provincial and Local Government and Meenakhsisundaram in Reddy 2010:67]. It is indicative of increasing global acceptance of an approach which is more democratic and participatory at the local level where services can be accessed more directly by empowering local communities and ensuring that they are integrated into the policymaking process.

According to the Guide to Decentralization of the Swiss Agency for Development and Cooperation (January 2001), decentralization can be used to pursue a number of objectives, broadly grouped into three categories:

- Improving relationships between the State and its people.

- Improving the effectiveness of governmental services.

- Improving the effectiveness of governmental services.

Improving relationships between the State and its people, means especially more political legitimacy of the State, also the central State; enhanced (democratic) participation of the local population, of minorities and women in political opinionbuilding processes; improved social integration of women and marginal groups; more control of power through the broader division of political power among various actors; the strengthening of a civil society in a structurally decentralized way to better play its role as a local counterbalance; and the protection of minorities and their specific interests and needs.

Improving the effectiveness of governmental services means especially that governmental tasks are performed on the level which is optimally suited to carry out the assignment. In line with the subsidiarity principle those tasks which primarily require local know-how and involvement should be performed by local authorities; public services are provided by governmental or nongovernmental actors, depending on competence and qualifications; more and better local services which also benefit the poor; more effective use of resources thanks to enhanced transparency, clearer distribution of responsibilities and accountability; services better responding to local needs and the the mobilization of additional local resources.

Promoting local development should focus on more context-adapted development programs and projects; greater utilization of local development potentials; improved economic balance between the center and the periphery; growing competence and capacities at the local level and more local ownership" 
At Intergovernmental level (Africa Union level), Ministers responsible for decentralization and Local Development in member States of the African Union are constituted by the decision of the Assembly of the Africa Union (Assembly/Au/Dec. 158 into All Africa Ministerial Conference on Decentralization and Local Development (AMCOD) as a specialized technical committee of the African Union in matters of decentralization and local development. AMCOD was established with the following objectives:

- Promote decentralization, local governance and participation of citizens and social groups in designing and implementing development policies;

- Include decentralization and local development in priorities of African government action;

- Sensitize all stakeholders of civil society to the primordial place of decentralization in the economic, social and cultural development of every nation;

- Provide intermediation between all African local authorities and their governments on all issues relating to decentralization and local development;

- Develop research and various studies in the area of decentralization and local development;

- Mobilize endogenous resources or resources form external partners for the execution of decentralization and local development programs;

- Formulate proposals for governments, for the optimal implementation of decentralization and the pursuit of local development in the African Union Member States;

- Encourage and support sub-regional groupings for the promotion of decentralization and local development [4, p. 3].

There has been some progress on decentralization in Southern Africa, more specifically in relation to the legislative and institutional arrangements. Some notable achievements includes, commitment to decentralize from the center; establishment of local government; intergovernmental fiscal policies and transfers and structures for community participation in local democracy and development involving women and special groups [7, p. 7]. Decentralization objectives in a number of Southern African states are summarized below. While this is hardly exhaustive of all the African countries in the SADC Region, these can serve as examples from which the rationale for decentralization can be deduced. The purpose is to highlight the complex job decentralized entities are being assigned.

\section{Decentralization Strategies and Processes in the Region}

In South Africa the national decentralization strategy has incorporated administrative, fiscal and political considerations. Developmental local government as characterized by its objectives and outcomes as an integral part of decentralization, as the notion of participatory participatory local democracy is being promoted (Reddy 2010:70; Cheema and Rondinelli 2007). The objectives of local government has 
summarized in Chapter 7 of the Constitution of the Republic of South Africa Act, 1997 (Act 108 of 1996):

- Provide democratic and accountable government for local communities

- Ensure the provision of services to communities in a sustainable manner.

- Promote social and economic development.

- Promote a safe and healthy environment.

- Encourage the involvement of communities and community organizations in the matters of local government.

Decentralization capacity is a major challenge in the South African context and the three spheres of government have to be strengthened and empowered in this regard [Reddy 2010:78].

There is no constitutional provision for local government in Botswana. The main legislative text is the Local Government Act of 2012. Other relevant legislation impacting on local government includes, inter alia Public Service Act of 2008; the Local Authority Public Procurement and Asset Disposal Act 2008 and Town and Country Planning Act of 2013 [8, p. 35]. Decentralization has been facilitated by the Town and Country Planning Act of 1980; National Development Plan (NDP) 1991 1997; National Development Plans 7, 8, 9 and 10 which proposed the drafting of a Decentralization Policy. The decentralization strategy followed has been creating a reasonable balance of power, resources and responsibilities between the center and four local institutions constituting local government. The positive includes considerable progress in the delivery of services. The trend has been deconcentration rather than devolution and decentralization is seen in terms of service delivery. However, there are other goals of service delivery like empowering local institutions to take control of processes that deliver services [11, p. 16 -17]. Some functions which were legally decentralized to local government such as the management and distribution of water have been taken back by the central government [7, p. 9].

Section 146 of the Constitution of Malawi made provision for the setting up of local government areas. A Decentralization Policy was adopted in October 1998 and revised in 2010 which facilitated the creation of an environment conducive for democratic governance, institutions and development at the local level. The Local Government Act was introduced in 1999 and revised in 2011. It makes provision for the establishment of local government and highlights their powers and functions [7, p. 8]. However, repeated postponements of the local government elections since 2005, when local authorities were dissolved have led to delays in the full implementation of decentralization.

The Constitution of Mozambique of 1996 makes provision for a legal framework for decentralization. The Local Government Act of 1997 established local government and granted them administrative and financial powers [7, p. 8]. "The tasks of local authorities are to: organize the participation of citizens in finding a solution to the community's problems; to promote local development; and to strengthen and consolidate democracy within the framework of Mozambican state unity" [8, p. 104]. Decentralization was emphasized in the strategic vision Agenda 
2015; Government's ten year Global Strategy for Public Sector Reform (2001 2011). Important decentralization achievements are the expansion of service delivery and gradual improvement of voter turnout in municipal elections. The challenges are the absence of formal policies on decentralization, although there has been decrees, national strategic plans and ministerial plans and programs; no clear conditions/benchmarks for municipalization; inadequate capacity used as an excuse not to decentralize and ensure that funds earmarked for poverty reduction is not retained at center, but transferred to districts and at the same time ensure that expenditure is monitored properly [11, p. $140-141]$.

The legal framework for implementing decentralization in Zimbabwe is facilitated by the District Councils Act of 1980; the Prime Minister's Directive of 1984; Provincial Councils and Administrative Act of 1985; Rural District Councils Act, Chapter 29.13 and the Urban Councils Act, Chapter 29.15 [7, p. 8]. In some cases, the national government issues directives which are counterproductive for decentralization and in some cases ultra vires. This has happened in Zimbabwe where in June 2006, the National Water Authority took over the management of water and sewage following a directive from the Minister of Local Government and the reasons advanced was the limited capacity of local governments to discharge these mandates [7, p. 9].

Some of the key challenges in implementing decentralization in Southern Africa includes, lack of consistency in the legal framework; inadequate human and financial resources; some resistance, particularly from line ministries; inappropriate financing mechanisms and unfunded mandates and the weakness of civil society [7, p. 20].

\section{Progress Towards the Millenium Development Goals}

The MDGs are a shared international development agenda and framework to address human poverty globally. It was ushered in 2011 following the 2000 Millennium Declaration that was signed by Heads of States and Governments. While there has been progress achieved in some of the key international development challenges that is, combatting poverty; control of Aids; school enrolment, child health and malaria and clean water access even in the poorest countries, it bears ample testimony to the fact that MDGs are achievable. However, despite the progress made, the impact on the lives of the poorest communities, particularly in Africa has been limited. The lack of a renewed and firm commitment for decisive action and the current economic crisis has meant that a significant number of countries will not achieve the MDGs by 2015. Consequently, serious consideration should be given to the ushering of a new post 2015 development agenda which will possibly extend the deadlines for the MDGs or complement them with a new development strategy which is all inclusive and comprehensive.

It is possible that the Region will achieve the universal primary education goal; however, rural water and sanitation, poverty, food insecurity, child malnutrition, gender equality, high child and maternal mortality, deforestation are likely to be 
major challenges. The HIV/Aids pandemic is on the increase in most countries and has reached double digit figures. This has to be viewed against economic performance which is weak, official development assistance which is declining, a high debt burden; food shortage and poverty and most of the countries being landlocked. In addition, economic growth is a major challenge in many of the countries as low, stagnating and declining growth characterizes the majority of the countries. This has impacted negatively on the attainment of the MDGs (World Bank 2005: 2).

The New Partnership for Africa's Development (NEPAD) was adopted in July 2002 to ensure sustainable regional integration; embracing positive African concepts; promoting self-reliance and self-sustainability. Capacity development has been identified as a major priority as highlighted by the following:

"State capacity building is a critical aspect for creating conditions for Development. The state has a major role to play in promoting economic growth and development and in implementing poverty reduction programs,...It is for this reason that targeted capacity building should be given a high priority. Programs in every area should be preceded by an assessment of capacity followed by the provision of appropriate support" [24, p. 9].

A program on public administration and governance aimed at ensuring that African states and governments have the capacity to govern effectively and deliver services efficiently was adopted by the PAN African Conference of Ministers of the Public Service held in May 2003. The World Bank has added that key issues critical to the success of MDGs in the SADC Region includes inter alia, political commitment or more specifically political will; efficient resource allocation in terms of alignment between national budgets and development priorities and strategic micro - economic frameworks and broad partnerships between governments, the private sector, non-governmental organizations and local communities [24, p. 10].

It has been pointed out that not only financial resources are important for the attainment of the MDGs, but also the institutional governance context in which the required intervention takes place. Strong resources are imperative for deploying all the resources of the State to achieve not only the MDGs, but also national development goals. It has been pointed out that the achievement of the MDGs can be more effective when undertaken at the local level, as decentralized systems of governance enables quicker and improved targeted delivery of basic services.

\section{Country by Country Analysis}

In Mozambique the goals of the MDGs have been reinforced in the National Agenda for the Fight against Poverty. There has been progress made in the expansion of the educational and health services as well as gender equality. A firm commitment has been made to manage the negative impact of climate change and more importantly address the issue of food security. This has been detailed in the 2010 Gender, Environmental and Climate Change Strategy and Action Plan. Three Presidential Projects, namely "Maternal and Child Health"; "One Student, One Tree per Year" and the "One Leader, One Community Forest" have been introduced to 
crystalize MDG challenges [16, p. 2]. The Government through substantial investments in education; health and supply of drinking water has endeavored to enhance the living conditions of the populace. In addition, the decentralization of resources to districts; the introduction of a District Fund and public private partnership bears ample testimony to the efforts of strengthening districts as poles of development. The principles of equality of rights/gender have been constitutionalized through articles 35/36 in a policy and strategy context. In addition, there are several other instruments such as Government - Five Year Program for 2010 - 2014; PARPA 2010 - 201; Gender Policy and Implementation Strategy; National Plan for the Advancement of Women; Sector Gender Strategies for Education, Health, Public Administration, Energy and Environmental Affairs which are key to the process. The commitment and political will relative to gender is documented in legislation and is an integral part of government programs [16, p. 540]. The constraints on the achievements of the MDGs are summarized below [16, p. 69]:

- Cumulative effect of the HIV/Aids pandemic has increased poverty levels at national level: attainment of MDGs necessitates poverty reduction by half;

- Quantity and quality of human resources limited for purposes of rotation and improvement/management of programs;

- Floods, cyclones and droughts has resulted in agricultural growth and production rates being very low or even zero;

- Job creating investment hampered by limited resources;

- Trade unions are weak in terms of technical capacity and coverage;

- Primary school population increase not accompanied by quality. A large number of those aged 6 do not have access to school and there is no legislation making primary education compulsory. The student/teaching ratio is very high and rural cultural habits has placed little emphasis on schooling;

- Issues of gender equality are more prevalent in the rural areas. Daughters not attending school as parents are afraid of sexual harassment or insecurity as there are more male teachers;

- Climate change has impacted negatively on natural resources and biodiversity as a result of cyclical floods, cyclones and droughts. There is limited training for importers about chemicals banned locally;

- External assistance subject to uncertainty and may decrease in real terms in the medium term.

The 2010 Government of Botswana/United Nations Progress Report highlights the fact that there has been progress made in the past five years and the 2004 levels of progress has been maintained. Poverty reduction policies and strategies facilitate the process of achieving the global goal of "halving the number of people living below the poverty datum line by 2015 ". In this context, there has been a decline in the percentage of people living below the poverty datum line by $24 \%$ from 1993 to 2009 . HIV and Aids still present major challenges to improving the lives of the people as well as diminishing the prospects of achieving the MDGs. The recent global financial 
and economic crisis has meant that the country has experienced a loss of income. In addition, the reduction in diamond sales will also impact negatively on the attainment of the MDGs and Vision 2016. The Government has to work closely with development partners to promote economic development and ultimately human development outcomes [15, p. 63]:

- the gap between good macro - economic and poor micro - economic performance has to be bridged. In the absence of this, there will be in high unemployment and poverty. Private sector development has lagged behind public sector investment;

- the Global Economic Crisis has resulted in the GDP contracting by 3.7\% and mining recording a decline of $20.9 \%$ and a growth of $6.2 \%$ in the economy.

- Mineral reserves growth which was lower was compounded by slower growth in other revenue sources and foreign exchange reserves;

- diversification and competitiveness in the economy is imperative and strategic public investments in communication; energy infrastructure, education and skills development are a priority. Emphasis has to be placed on quality and efficiency;

- emphasis should be placed on technology driven business as the country is landlocked. Disadvantages of cost as a result of no access to the ocean are mitigated.

In order to achieve its key developmental objectives, the Government has actively intervened in the economy, through inter alia the National Export Strategy (NES); National Trade Policy; Botswana Industrial Development Policy Investment Strategy; Export Development Program and Competition Policy Law and an imminent policy on Special Economy Zones.

South Africa is viewed as being in the middle income group and is one of the few on the Continent that has adequate data in reporting progress on the MDGs. Comparatively and continentally, the country does stand out from the rest as it reflects a mixed picture in terms of the MDG goals [18, p. 2-3].

Some of the MDG targets have already been met and in the case of those not, the country is on track to achieving them. Generally economic growth has been on an upward swing with the possible exception of 1998 which can be attributed to the crisis in East Asia and related factors. Since 1994, various legislative, institutional and administrative measures were introduced to ensure an enhanced quality of life for the majority of the citizenry as enshrined in the Constitution. In pursuance of this strategic goal, there have been several assessments over the years to ensure that the Government was on track with this overarching goal. These includes the Ten Year Review; Government Program of Action; Budget Votes; Speeches and Parliamentary Briefings and State of the Nation Addresses [Republic of South Africa 2007:9].

In addition, there has been several other initiatives introduced of late to assist other African countries achieve the MDGs. The country was instrumental in ushering in the New Partnership for Africa's Development (NEPAD) which is a socio economic framework for development and more importantly the main instrument for 
achieving the MDGs [Republic of South Africa.2007:9]. To a large extent, it has been mainstreamed in the development agenda of the Continent and has played a pivotal role in terms of informing the national framework for policy formulation and planning at a country level. The country has also participated in international structures that seek to develop the global developmental agenda. Critical to that process is regional integration continentally.

Consequently, the achievements of the MDGs are probable and possible. However, appropriate government interventions are imperative for making these goals achievable [18, p. 3]. In terms of positives, the country has a private sector which is reasonably well developed, sophisticated infrastructure and a macro economy which can be described as stable. However, it has to be pointed out that the quality of education and healthcare despite being accessible is far from satisfactory. The latter seen together with the high prevalence of HIV/Aids has meant that several targets has not been reached in terms of the MDGs, notably in relation to employment; income levels as well as life expectancy. Given that South Africa is not dependent on donor funding, meeting and improving on the MDGs depends to a large extent on how domestic resources are mobilized by the Government and other stakeholders to meet the targets. The growth rate has reached 5\%; however, a figure of $7 \%$ is required to reach employment and redistributive targets. Poverty levels have declined due to inter alia, a major reallocation of pro - poor expenditure to basic services provision (housing, water, electricity and sanitation) and a significant income transfer program [18, p. 3].

The implementation of the Millennium Development Goals in Malawi was facilitated through medium term strategies which were then translated into annual budgets. The first three year strategy was the Malawi Poverty Reduction Strategy (PPRS) implemented from 2000 to 2005. The review for the 2005 Malawi Poverty Reduction Strategy pointed out that as much as the Strategy emphasized poverty reduction, not much emphasis was placed on the economic aspects. It was apparent that if the Government was to make reasonable progress towards the attainment of the MDGs, it had to remodel its development strategy [11]. The 2006 - 2011 Strategy emphasized wealth creation and sustainable economic growth as a mechanism for poverty reduction and human development. Furthermore, the Government used the MTEF and the Public Sector Investment Program to facilitate the smooth implementation of the MDGs. Malawi Growth and Development Strategy which initially focused on six strategic areas which has since been reduced to one in 2009 . There is a firm belief that the successful implementation of the priority areas will impact positively on the achievement of the MDGs and other pertinent development indicators.

The 2010 assessment has indicated that the Government is on track to attaining the MDGs by 2015 [10, p. 111]. The implementation, monitoring and evaluation mechanisms have been set up to provide feedback on the MDGs. It is viewed as being positive and points to at least five of the goals being achieved. There was some certainty in the other three not through lack of effort to achieve them, but do to the 
fact that the country had a much lower starting base comparatively. The targets to be achieved are eradicating extreme poverty; reducing infant mortality; combatting HIV Aids, Malaria and other diseases; ensuring environmental sustainability and developing global partnerships for development. Those that are in doubt are achieving universal primary education, reducing gender equality and infant mortality $[10, \mathrm{p}$. xi]. The achievement of the MDGs is to a large extent dependent on available resource and the Government has committed tax revenues to MDG related interventions. In addition, several policies and strategies have been developed to ensure that by 2015 , most if not all the MDGs will be attained. Developing public sector capacity has been prioritized by the government; however, limited action has been taken and the impact modest. The limited effectiveness of capacity building initiatives can be attributed to the fact that government has not laid down clear capacity development goals and furthermore there is no clear national capacity development strategy or clear champion within government $[24$, p. 11]

It is generally accepted that the central government in both developed and developing countries are responsible for providing the majority of the funds for local government. However, poor revenue collection is a major weakness in the majority of the African countries and because of this our main focus in this part is the fiscal decentralization, but also provide assessment for local services delivery and of human resources capacity on the local level.

\section{Fiscal Decentralization}

In Mozambique, there has been a decline in donor funding and the probability is overwhelming that this trend is likely to continue. Consequently, a major priority would be developing the local revenue base. In this context, Kathyola and Job (2011:181) point out that although there is tremendous potential for revenue collection, there has been no concerted effort to capitalize on this and even something basic like parking and property taxes are not collected.

Municipalities in Botswana are legally empowered to collect certain taxes, levies and fees to cover their operating expenses. Local revenue sources includes rates, service levies and user charges, including clinic and abattoir fees, trade licenses, beer levy, interest on investments, housing rents and alternative sources of revenue. Property and business tax are applicable to both urban and district councils since 2012 [8, p. 36]. Urban councils in Botswana are reliant on central government for the major source of their revenue (approximately 80\%) while in rural district councils it is even higher (97\%).The traditional sources of revenue have been identified as property taxes; levies on service charges; interests on deposits and rent on council properties. Local authorities have the opportunity to generate higher sources of income, but the rate for services, property taxes and municipal rent is set by the national government. Councils also receive development grants from the central government. Given that the domestic government revenues in Botswana are generated principally by national taxes and mining, the revenue is pooled and shared between the local and central government. It would appear that municipalities are quite content to continue with the 
current status quo as they tend to rely on grants from the national government [11, p. 181].

The post 1994 local government dispensation in South Africa has seen the demand for the upgrading, rehabilitation or replacement of ageing assets and economic infrastructure being increased considerably. More importantly, the nature and location of poverty has also been changing [17, p. 54]. Poverty is still widespread despite a redistributive intergovernmental fiscal system being in place. The resultant effect has been limited socio economic development. Although there has been some progress noted, it seems that the system generally has not been responding effectively to the challenges highlighted. A significant number of municipalities cannot leverage funds required for their basic municipal functionality. Problems like inter alia, audit reports which are uniformly poor; inability to manage financial statements and systems and processes described in the Municipal Finance Management Act has meant that compliance with the financial management system is a recurring challenge. In addition, other issues impacting negatively on the financial environment includes inter alia, weak skills base; limited support from the provinces; poor political and management oversight resulting in fraud and abuse and the onerous implementation of the Property Rates Act due to uneven application of processes, software and systems [17, p. 54].

Unfunded mandates have increased in South Africa despite the required protection being detailed in section 9 and 10 of the Local Government: Municipal Systems Act, 2000. Cloete in Reddy (2012) has pointed out that this state of affairs has come about as national and provincial government cannot discharge their own obligations.

In Malawi, the government has to ensure in terms of the Constitution that adequate resources are available for the effective delivery of devolved functions. The Local Government Act and the National Decentralization Policy provide for all sources of revenue where councils can charge or collect fees and levy rates. The Ministry of Local Government in consultation with relevant sectors of government, depending on the types of services, provides direction on how these can be determined. In accordance with the Constitution, there are two types of grant transfers from central to local government. In terms of the Constitution, $5 \%$ of the net government revenue should be transferred to local authorities. This ensures that adequate resources are available for the effective local delivery of devolved functions and more importantly to address under collections. An approved formula reviewed regularly governs the transfers. The formula is the preferred mechanism to facilitate the process as it ensures fairness, transparency, accountability and equality across the different regions. On an annual basis, it is anticipated that a total of $29 \%$ of the national net revenue will be devolved to local government.

Following independence in 1980, Zimbabwean local authorities have been experiencing considerable difficulties in raising the required funding to finance the efficient and effective delivery of municipal services, In this context, some of the challenges have been highlighted by Coutinbo (2010:X1V) as inter alia, financial 
management systems viewed as being inadequate; cost recovery on essential services viewed as being ineffective; debt recovery deemed to be insufficient amidst hyperinflation; lack of qualified staff who have moved into the private sector or have emigrated and poor financial accounting systems. Local governments are generally sustaining themselves financially although there has been a serious decline in local government transfers ${ }^{24}$ [7, p. 32]. Coutinbo (2010:X1V) adds that interventions in law reforms such as compliance in terms of International Financial Reporting Standards are also ensuring that citizens are actively involved in preparing the budget needs to be addressed. In addition, the accountability to Parliament and the relevant Minister by the local government sphere has to be taken more seriously. To summarise, we may argue that there are certain distinct challenges relative to local government financing in the Region, as noted by Wright [25, p. 4]:

- A variation in the extent of fiscal decentralization and powers;

- There are very few local resources;

- There has been a failure to maximize revenue collection;

- Increasing reliance on central/local fiscal transfers;

- There is no consistency in fiscal transfers which can be quite unpredictable;

- There has been a lack of sustainability and donor dependence

- Lack of strategic engagement with the private sector; and

- There should be greater accountability and transparency to combat corruption.

\section{Local Service Delivery/Infrastructure}

In South Africa, basic service delivery has increased considerably following the ushering in of local democracy twenty years ago. The national government has facilitated the process relative to policy reforms, legislation and funding. However, a few municipalities have the institutional capacity and stability to discharge their developmental mandate as opposed to the majority of them which are facing serious economic and human resources capacity challenges. Consequently, the overall situation is far from satisfactory [17, p. 34]. The Local Government Turnaround Strategy Report (2009:35) also placed considerable emphasis on several issues which needs urgent attention, namely a legacy of infrastructure backlog; capacity constraints in relation to delivery and funding; increasing urbanization; public participation which is credible; key infrastructure in rural areas which is lacking and informal settlements which has been increasing. The socio - economic conditions among the municipalities tends to vary and municipal competence has also resulted in service delivery being uneven nationally. Provincial assessments of individual municipalities has highlighted other critical issues that has to be addressed in the broader context of

\footnotetext{
${ }^{2}$ In 2006, local governments were self funding by $90 \%$ whereas in 2010 and 2011 they were receiving less than 1\% of national recvenues (CLGF/UNCDF/CLGF 2012:32).
} 
monitoring and evaluation, notably wastage, underspending; poor oversight and inappropriate usage of funds [17, p. 40].

The national Ministry in charge of local government sets standards in terms of which service delivery is measured in Botswana. Although the approach to service delivery may be described as technocratic, there is a compulsion for public institutions including local authorities to be discharging their obligations [11, p. 216]. Kathyola and Job point out that the quality of service delivery is monitored through (1) quality of services that clients/users receive is assessed through "public service customer satisfaction" surveys organized by the Public Sector Reforms Unit of the Office of the President. The quality of services is high comparatively in the African context. There has been progress generally even in relation to the MDGs. However, there is some disparity between the urban and rural areas; (2) there is some duplications and ambiguities of responsibilities in the institutional arrangements for service delivery as the work is carried out by deconcentrated sectoral agencies and departments, each with their own budget and employees. This applies to education; health; housing and sanitation (2012:46-47).

In the case of Mozambique, some of the local government responsibilities have been transferred to the market through privatization and public - private partnerships. According to Cramer (Kathyola and Job 2012:171), the privatization program has been the largest in Sub- Saharan Africa and possibly one of the most successful in Africa. However, private sector participation has been poor in the municipal sector, with only a few urban municipalities contracting out solid waste collection to private companies. In addition, the management of municipal parks and gardens has also been privatized. NGOs working with donor agencies have been quite active in primary education, water, health and other basic infrastructural services (Kathyola and Job 2012:172). The key objective of decentralization is improved service delivery. It is believed that provision of basic services has improved in the rural areas due to a massive injection of government funds. Access to potable water has increased from $37.1 \%$ to $48.5 \%$; coverage of pit-hole latrines is currently $39 \%$; urban water supply has increased from $31.2 \%$ to $40 \%$; primary school completion rate has increased from $38.7 \%$ to $72.6 \%$. It is possible that the number of people without access to safe drinking water could be reduced by half in terms of MDG targets (Kathyola and Job 2012:176-177). Local governments in Zimbabwe are experiencing serious challenges in delivering services to their communities as evidenced by the poor state of the road network, failure to supply clean water and uncollected refuse. The reasons for this failure can be attributed to:

- failure to collect adequate revenue due to poor collection methods; inability to link revenue to service provision and the general economic situation in the country;

- inappropriate knowledge, skills and attitude - poor connection with communities, resulting in lack of ownership and participation in council programs; 
- no strategic and development planning being carried out by local government;

- unfunded mandates as a result of decentralized services [7, p. 64].

Service delivery in Southern Africa has shown signs of stress and in some cases indications of possible failure. Some of the service delivery challenges can be summarized as follows:

- weak end user and service provider interactions which are strained resulting in institutional mistrust and stress. This tends to undermine the processes of civic engagement; institutional collaboration; planning and management of the new service;

- inadequate resources: resource constraints tend to curtail service delivery and more specifically inclusive service delivery. Efficient deployment and management of resources, notably human will impact positively on service delivery;

- rapid urbanization: the municipality's capacity to provide adequate services or expand existing coverage has been far outstripped. This is due to growth in urban areas and improved lifestyles;

- political and policy interference: where party cadres are appointed at local level or the politicization of local issues;

- institutional coordination problems: overlapping mandates and wasteful duplication and poor co - ordination;

- malpractices: corruption; poor procurement systems and bureaucratic inefficiencies burden service delivery;

- weak traditions of participation: often leads to limited citizen consultation;

- research and technological limitations: application of appropriate technologies that ensures efficiency;

- planning and budget tracking: participatory long and short - term planning systems ensures a good opportunity to apply inclusive service delivery [7. p. $48-50)$.

Wright $[25$, p. 6] adds that there is a need for inclusiveness in terms of meeting the needs of the marginalized/disadvantaged groups; pressures of rapid urbanization which has led to migration; poor service quality and accessibility; problems around capacity and resources and the need for monitoring and assessment of quality control. In addition, there has to be a link to the post 2015 sustainable development agenda in in terms of local target setting and implementation.

\section{Human Resources Capacity}

In Mozambique, $8.1 \%$ of public servants have university degrees; $25.69 \%$ have completed their high school education and $42.04 \%$ have completed their basic education. $3.4 \%$ of those public servants with university degrees are working in the districts, outside the provincial capitals. Consequently the educational level of the public servants will to a large extent impact on the quality and competence of 
government machinery to develop and implement programs [11, p. 167]. There has been training offered to public servants; however, to date it has not been evaluated in terms of effectiveness to develop the type of competencies required by municipal public servants. In addition, there are a large number of civil servants that have to be trained [11, p. 167].

The establishment of the Department of Local Government Service Management in Botswana which is responsible for recruitment; transfer; training and dismissal has resulted in greater uniformity in local government employment. The Department of Corporate Services within MLDRD is responsible for human resources matters for all senior staff in all local authorities. The administrative head of the councils and the urban and rural districts are the town clerks and council secretaries respectively. Local authorities have the responsibilities for lower graded staff. Councilors receive remuneration determined by the central government. The mayors in towns and council chairpersons in rural districts provide strategic leadership [8, p. 36]. Although centralization of the processes has increased, there is still active involvement by local authorities. Kathyola and Job [11, p. 167] observed that the competence of district council employees has increased over the years as many heads of departments have university degrees with a few of them having masters' degrees. In addition, short and long term training programs has played a pivotal role in developing capacity. However, the challenges are the exclusive loyalty of local government staff to central government and the centralized systems in recruitment, dismissal and disciplinary action at the local level [11, p. 167].

A best practice local governance system which is constitutionally and legislatively entrenched was ushered in post 1994 in South Africa. The large number of service delivery protests of late throughout the country points to the fact that all is not well and that basic constitutional values and principles and relevant legislation is not being adhered to. Failures in municipal service delivery have its origin in several factors, namely unstable political governance; irregular/ inappropriate appointments (limited/poor capacities and skills) and weak institutional management. It would appear that a significant number of district and local municipalities cannot even discharge their traditional functions. The rural areas have their own added challenges like limited understanding of the socio - economic and spatial realities and access to skills. Consequently, the capacity to deliver is lacking and the resultant effect is that they cannot deliver on their constitutional mandate [17, p. 33]. In this context, Tapscott in Reddy (2012:12) add that in "some areas, the municipality cannot be considered to be operationally functional, while only a small proportion of municipalities may be considered administratively effective".

In Malawi, in terms of Local Government Act, 1998, municipalities are responsible for human resources administration. A legislative amendment in January 2001 transferred responsibility for the recruitment of senior management staff from municipalities to the Local Government Service Commission which has responsibility for inter alia, the recruitment of the chief executive/district commissioner; directors of finance; internal audit and two finance officers responsible for recurrent revenue and 
development matters, administration; management information systems and public works. The Commission is an independent body that was originally set up in 1984 to support local government but was later disbanded. However, it has now been re activated on an interim basis until municipalities have developed the capacity to assume full responsibilities for recruitment. Responsibilities are retained by council for all other staffing matters. In addition, they have discretionary powers to organize secondments.

\section{Challenges, Capacity Gaps and how to Address them}

There are similar challenges at individual, institutional and systemic levels. As indicated above, the gaps are in relation to lack of resources, both human and financial; lack of skills as qualified staff members leave for greener pastures and lack of political will to complete the decentralization process [7, p. 58].

At the individual level, there has been a skills flight as people have tended to move to greener pastures. There is a shortage of skilled manpower, poor conditions of service; technical departments adversely affected; migration of qualified personnel and low levels of remuneration. In addition, staff needs to be innovative and creative in term of dealing with issues like PPPs [7, p. 58].

The challenges at the institutional level are financial (which undermines government effectiveness and legitimacy); local government planning is not participatory and furthermore the issue of unfunded mandates.

At the systematic level, there has been a lack of comprehensive and sustainable capacity development focusing on inter alia community mobilization; community based monitoring and evaluation; public private partnerships; participatory planning and budgeting. Political will and ownership; contested political and administrative interface; weak oversight and support from higher level institutions are still a challenge [7, p. 58].

In such situation the core proposals for a way forward relative to revenue mobilization, service delivery and capacity development in the SADC Region include issues like: localization of the new sustainable goals, in terms of local targets, notably empowerment of developmental local government; there should be an LED strategy in place in partnership with the private sector; ensure fiscal decentralization with a view to generating new local resources; there should be mechanisms in place to facilitate intergovernmental relations; greater political will by both the politicians and political parties; and development partner support for local government capacity development $[24$, p. 8]. To address existing challenges, from the regional level, we may argue that there are several role-players and stakeholders in local government capacity building and they can be summarized as follows:

- Local Government Associations: which is the collective interface between local government and respective governments. They cater for member's common needs and interests and provide an opportunity to exchange information. More specifically, they are responsible for lobbying and advocacy; capacity development and a platform for information exchanges; 
- Central Government: responsible for providing policy guidance, technical support and capacity development. They work closely with development partners in supporting capacity development through workshops; formal skills upgrades, equipment and technical support;

- Tertiary institutions like universities offer specific capacity development programs that impact on local government [7, p. 58].

Capacity development is a cross cutting issue and an integral part of human resources development. There has to be political and management commitment and clearly defined roles and responsibilities to ensure success in terms of organizational development. The linkage with the tertiary institutions is important. In terms of facilitating capacity development at the local level.

\section{Conclusion}

1. In reviewing the overall assessment of the progress made by the sample of countries in attaining the Millennium Development Goals, service delivery and revenue mobilization, it is quite apparent that progress has been made reaching some of the targets set for the MDGs for 2015 and overall enhancement of the local government system. Overall, the general performance of local government in the Region can be summarized as mixed and inadequate. There are still considerable disparities relative to performance and progress across the Region and it is generally accepted that the higher income communities tend to by and large access basic services. Distinct challenges in relation to education; health; water and sanitation have compounded the problems of marginalized groupings.

2. However, African countries have to as a matter of urgency prioritized strong economic growth which in the final analysis has to be translated to job creation and poverty reduction. Political will which does constitute a major challenge in terms of moving towards the MDGs is critical to the process. It is imperative that there is regular monitoring to evaluate performance on the MDGs. Consequently, monitoring if it is going to be effective requires considerable investments in research and dissemination as opposed to what is happening at present. It has been pointed out that "improved data coverage and quality, particularly at sub - national levels are critical for unmasking intra - country variations on MDG performance in identifying pockets of vulnerability as a basis for targeted interventions".

\section{References}

1. Abdul - Hakim, A. I. 2004: Decentralization in SADC Countries: Transformation and Challenges. Unpublished LLM Dissertation. Cape Town: University of Western Cape.

2. African Development Bank Group/ Economic Commission for Africa/African Union and United Nations Development Programme.2010. Assessing Progress in Africa toward the Millennium Development Goals. New York. 
3. African Development Bank Group/ Economic Commission for Africa/African Union and United Nations Development Programme.2011. Assessing Progress in Africa toward the Millennium Development Goals. New York.

4. AMCOD. 2010. Constitution of the All Africa Ministerial Conference on Decentralization and Local Development (AMCOD). Yaounde. September.

5. Cheema, S and Rondinelli, D. 2007. Decentralizing Governance: Emerging Concepts and Practices. Ash Institute for Democratic Governance and innovation.

6. Constitution of the Republic of South Africa Act, 1996 (Act 108 of 1996).

7. Commonwealth Local Government Forum (CLGF)/United Nations Capital Development Fund (UNCDF) and United Nations Development Programme (UNDP).2012.Local Governments in Southern Africa: An Analytical Study of Decentralization, Financing, Service Delivery and Capacities. New York.

8. Commonwealth Local Government Forum.2013 Commonwealth Local Government Handbook 2013/2014. London: Publications UK Limited.

9. De Visser, J; Stetyler, N and Machingauta, N. 2010. Local Government Reform in Zimbabwe: A Policy Dialogue. Cape Town: Community Law Centre of the University of the Western Cape.

10. Government of Malawi. 2010. Malaw Millennium Development Goals Report. Ministry of Development Planning and Co - operation. Lilongwe.

11. Kathyola, J. and Job O. 2011. Decentralization in Commonwealth Africa: Experiences from Botswana, Ghana, Mozambique and Tanzania. London: Commonwealth Secretariat.

12. Reddy, P. S.2013. Democratic Decentralization and Local Democracy in South Africa Re - examined: Quo Vadis? Politeia - South African Journal for Political Science and Public Administration. Vol. 29. No. 3. 2010.

13. Reddy, P. S. 2013. Local Government Capacity Development, Local Economic Development (LED) and Inclusiveness: A Critique of the South African Experience. Paper presented at the 2013 Research Colloquim of the CLGF, 13 - 13 May 2013. Uganda.

14. Reddy, P. S. and Govender, J. 2012. Democratic Decentralization, Citizen Engagement and Service Delivery in South Africa: A Critique of Legislative and Policy Considerations, Africanus - Journal of Development Studies. Vol. 43 (1).

15. Republic of Botswana/United Nations. 2010. Botswana Millennium Development Goals: Status Report. Botswana: Ministry of Finance and Development Planning. Gaborne.

16. Republic of Mozambique. 2010. Report of the Millennium Development Goals. Maputo, September.

17. Republic of South Africa. 2009. State of Local Government in South Africa: Overview Report. Pretoria: Government Printer.

18. Republic of South Africa. 2010. Millennium Development Goals: Country Report 2010. Central Statistics Office. Pretoria: Government Printer.

19. Organisation for Economic Co - operation and Development.2006.The Challenge of Capacity Development: Working towards Good Practice. Paris: OECD. 
20. Government of Botswana/UNDP.2010.Botswana Millennium Development Goals: Status Report. Ministry of Finance and Planning. Botswana.

21. Swiss Agency for Co - operation and Development. 2001. Guide to Decentralisation. Switzerland. January.

22. United Nations. 2009. Addendum to the $2^{\text {nd }}$ Guidance Note on Country Reporting on the Millennium Development Goals. New York: UNDP. November.

23. United Nations Development Programme (UNDP). 2011. Response Institutions: Local Governance. Also available on www.undp.org/governance accessed in 2012.

24. World Bank. 2005. An Independent Review of World Bank Support for Capacity Building in Africa: The Case of Malawi. Corporate Methods Evaluation Department. Washington

25. Wright, C. 2014. "Local Government SADC and International". Presentation to the Discipline of Public Administration at the University of Kwazulu Natal on the 20 March 2014. Durban.

26. www.mlgurd.gov.zw?about the ministry: accessed on 9 April 2014.

Purshottama Reddy, John-Mary Kauzya

\title{
Vietos valdžios gebėjimai Pietų Afrikos Vystymo Bendruomenès (PAVB) regione
}

\author{
Anotacija
}

Adekvatūs šalies gebejjimai yra svarbiausia globalinių pastangų aplinkybė pasiekti Tūkstantmečio vystymosi tikslus. Ekonominio bendradarbiavimo ir plètros organizacija pastebejjo, kad net jei būtų didesni finansiniai ištekliai gebejjimų vystymui, vis viena šis procesas, tikètina, sužlugtų. Gebėjimų vystymas iškilo virš individo lygmens žinių ir ịgūdžių požiūriu i viešosios institucijos ir organizacijos lyderystès ir vadybos kokybès dèmesio centrą. Tačiau nepriklausomai nuo valdžios sandaros, globaliai vietos valdžios atlieka krtitinị vaidmenị vietos valdyme skatindamos vietos vystymąsi ir galiausiai Tūkstantmečio vystymosi tikslų(TVT) siekimą. Vis dèlto viešojo valdymo lygis daugelyje šalių vis dar yra per silpnas, kad darytų reikšmingą poveikį spartinant TVT pasiekimą (UNDP 2011:1). Šis straipsnis kritiškai apžvelgia Tūkstantmečio vystymosi tikslų siekimą Pietų Afrikos Vystymo Bendruomenès (PAVB) regione su ypatingu vietos valdžios išskyrimu. PAVB regioną šiuo metu sudaro dvylika šalių, tačiau ši studija amalizuoja reprezentatyvų šalių pavyzdị, būtent Pietų Afriką, Botsvaną, Malavị, Mozambiką ir Zimbabvę. Šios šalys skiriasi savo dydžiu, fiziniais požymiais, politine dinamika ir išsivystymo lygiu. Adekavtūs gebejjimai yra vienas kritinių trūkstamųjų veiksnių dabartinèse pastangose pasiekti TVT ir kitus nacionalinio vystymosi tikslus. Politinè valia, stebėsena ir vertinimas yra esminès aplinkybès palengvinančios vystymosi procesą ir TVT pasiekimą.

Purshottama Reddy - Professor, coordinator of Management Development Programs in Kwazulu Natal, SAR.

E-mail.: reddyp1@ukzn.ac.za

John-Mary Kauzya - Dr. Chief of Public Administration Capacity Branch (PACB), 
Division for Public Administration and Development Management Departament of Economic and Social Affairs United Nations New York

E-mail.:kauzya@un.org

Purshottama S. Reddy - profesorius, vadybos vystymo programų koordinatorius (Kwazulu Natal, PAR)

E.paštas: reddyp1@ukzn.ac.za

John-Mary Kauzya - daktaras, Jungtinių Tautų Ekonominių ir socialinių reikalų departamento Viešojo administravimo ir plètros vadybos padalinio Viešojo administravimo gebejjimų skyriaus vadovas

E.paštas: kauzya@un.org

Straipsnis įteiktas redakcijai 2015 m. rugpjūčio mèn.; recenzuotas; parengtas spaudai $2015 \mathrm{~m}$. rugsèjo mèn. 